\title{
Residue 315 regulates V3 exposure and V3 antibody recognition on HIV subtype $B$ and $C$ viruses
}

\author{
S Manhas ${ }^{\text {* }}$, B Clark', MK Gorny², S Zolla-Pazner², R Pantophlet ${ }^{1}$ \\ From AIDS Vaccine 2012 \\ Boston, MA, USA. 9-12 September 2012
}

\section{Background}

V3 mAbs often neutralize HIV subtype B viruses but exhibit poor neutralizing activity against subtype $\mathrm{C}$ viruses. This limited activity is typically attributed to masking of the V3 region on subtype $\mathrm{C}$ viruses. However, while relatively much effort has been devoted to exploring accessibility of the $\mathrm{V} 3$ region on subtype $\mathrm{B}$ viruses, V3 exposure and the mechanism(s) that might restrict V3 exposure on subtype $C$ viruses has yet to be understood. Here we have focused on exploring the significance of the conserved V3 tip motifs GPGR and GPGQ of subtype $\mathrm{B}$ and $\mathrm{C}$ viruses for antibody recognition.

\section{Methods}

Position 315 in representative subtype B (SS1196) and subtype C viruses (ZM249M, CAP45) was switched to Gln and Arg, respectively, to assess the effect of the conserved Arg/Gln at position 315 on V3-specific neutralization. Neutralization sensitivities of the parental and mutant viruses were assessed in a single-round pseudovirus neutralization assay using a panel of neutralizing V3-specific $\mathrm{mAbs}$ with varying fine specificities for the V3 tip.

\section{Results}

Subtype B virus SS1196 was neutralized by all V3-specific mAbs tested here (B4e8, 2219, 268-D, 2557, 3074 and HGN194). In contrast, though as expected, mutant SS1196_R315Q was resistant to neutralization by mAbs B4e8 and 268-D, both of which require the Arg at position 315 for binding. Unexpectedly, the remaining V3 mAbs were also unable to neutralize SS1196_R315Q, despite not requiring an Arg residue at position 315 for binding. For

${ }^{1}$ Simon Fraser University, Burnaby, Canada

Full list of author information is available at the end of the article the subtype $C$ viruses the exact opposite was observed; both ZM249M and CAP45 were generally insensitive to antibody neutralization yet the Q315R mutants were strikingly sensitive.

\section{Conclusion}

The results suggest that V3 may be more accessible to antibody than previously appreciated in at least some subtype $\mathrm{C}$ viruses. However, the data also suggest that a Gln at position 315 modulates exposure of V3. Further elucidation of this mechanism is underway.

Author details

${ }^{1}$ Simon Fraser University, Burnaby, Canada. ${ }^{2}$ New York University School of Medicine, New York, NY, USA.

Published: 13 September 2012

doi:10.1186/1742-4690-9-S2-P54

Cite this article as: Manhas et al:: Residue 315 regulates V3 exposure and V3 antibody recognition on HIV subtype $B$ and $C$ viruses.

Retrovirology 2012 9(Suppl 2):P54.

Submit your next manuscript to BioMed Central and take full advantage of:

- Convenient online submission

- Thorough peer review

- No space constraints or color figure charges

- Immediate publication on acceptance

- Inclusion in PubMed, CAS, Scopus and Google Scholar

- Research which is freely available for redistribution 